\title{
Penggunaan Metode Team Games Tournament pada Pembelajaran Tematik untuk Meningkatkan Keaktifan Belajar Siswa
}

\author{
Shalahudin, ${ }^{*}$ Widiya Wati \\ Universitas Islam Negeri Sulthan Thaha Saifuddin Jambi \\ *Penulis korespondensi: sholahuddin@uinjambi.ac.id
}

DOI : https://doi.org/10.21580/jieed.v1i2.7581

Received: 2021-02-16, Revised: 2021-02-27,

Accepted: 2021-03-03, Published: 2021-11-06

\begin{abstract}
Abstrak
Tujuan penelitian ini adalah untuk penggunaan metode teams games tournament untuk meningkatkan keaktifan belajar siswa di dalam proses pembelajaran materi keragaman suku bangsa dan agama di negeriku. Subjek penelitian tindakan kelas ini adalah kelas IV SD Negeri 59/IX Penyengat Olak. Teknik pengumpulan data penelitian ini adalah observasi, wawancara, dan dokumentasi. Analisis data dilakukan dengan menggunakan analisis kuantitatif yang terdiri dari reduksi data, penyajian data, penarikan kesimpulan. Hasil penelitian ini menunjukkan bahwa penggunaan metode teams games tournament dapat meningkatkan keaktifan belajar siswa dalam proses pembelajaran. Keaktifan belajar siswa pada siklus I adalah sebesar $61 \%$ dan pada siklus II adalah sebesar 93\%. Hasil penelitian ini menunjukkan bahwa penggunaan metode team games tournamen dapat meningkatkan keaktifan siswa di dalam proses pembelajaran dan mencapai kualitas pembelajaran yang tuntas.
\end{abstract}

Kata Kunci: keaktifan belajar, model pembelajaran teams games tournament, pembelajaran tematik

The Use of the Team Games Tournament Method in Thematic Learning to Improve Student Learning Activities

\begin{abstract}
The purpose of this study is to use the teams games tournament method to increase student learning activity in the learning process of ethnic and religious diversity in my country. The subject of this class action research is grade IV SD Negeri 59/IX Penyengat Olak. The data collection techniques of this study were observation, interviews, and documentation. Data analysis was carried out using quantitative
\end{abstract}


analysis consisting of data reduction, data presentation, and conclusion drawing. The results of this study indicate that the use of the teams games tournament method can increase students' active learning in the learning process. Student learning activity in the first cycle is $61 \%$ and in the second cycle is $93 \%$. The results of this study indicate that the use of the team games tournament method can increase student activity in the learning process and achieve complete learning quality.

\section{Keywords: learning activities, teams games tournament learning model, thematic learning}

\section{PENDAHULUAN}

Keaktifan siswa di dalam proses pembelajaran sangat menentukan kualitas pembelajaran. Oleh karena itu, guru harus mampu merancang pembelajaran yang dapat meningkatkan keaktifan siswa di dalam proses pembelajaran tematik. Mulyasa dalam Nuryani (2014) menjelaskan bahwa pembelajaran dapat dikategorikan berkualitas jika sebagian besar peserta didik berpartisipasi secara aktif dalam pembelajaran. Hal ini menunjukkan bahwa upaya guru dalam meningkatkan keaktifan belajar siswa sangat penting sebab keaktifan siswa menjadi penentu bagi keberhasilan pembelajaran yang dilaksanakan.

Pembelajaran adalah penyederhanaan dari kata belajar dan mengajar, proses belajar mengajar atau kegiatan belajar mengajar. Pembelajaran yang diidentikan dengan kata"mengajar" berasal dari kata dasar "ajar" yang berarti petunjuk yang diberikan ke pada orang supaya diketahui. Kata pembelajaran yang semula diambil dari kata"ajar" ditambah awalan "pe" dan akhiran "an"menjadi kata "pembelajaran" artinya sebagai proses, perbuatan, cara mengajar, atau mengajarkan sehingga anak didik mau belajar (Ahmad Susanto, 2016: 18-19). Menurut Batubara (2021), pembelajaran adalah peristiwa yang di dalamnya terdapat kegiatan belajar dan mengajar (KBM). Dengan demikian, pembelajaran adalah menyampaikan pengetahuan melalui peserta didik agar dapat menumbuhkan pengetahuan kognitif, afektif dan psikomotorik pada peserta didik.

Keaktifan belajar terdiri dari kata "aktif" dan kata "belajar". Keaktifan belajar adalah suatu usaha atau kegiatan yang dilakukan dengan giat belajar (Nurhayati, 2020). Keaktifkan belajar juga diartikan sebagai upaya siswa dalam mengembangkan potensi diri melalui serangkaian proses kegiatan belajar, baik pembelajaran secara tatap muka maupun pembelajaran secara daring untuk mencapai tujuan belajar (Prasetyo \& Abduh, 2021). Menurut Sareong dan Supartini (2020), keaktifan belajar berarti kemampuan peserta didik untuk menyusun dan membangun sendiri pengetahuan yang didapat melalui proses belajar.

Keaktifan belajar siswa dapat diketahui dari partisipasi siswa dalam: bertanya kepada guru dengan jelas, menjawab pertanyaan yang diajukan guru dengan baik, mengemukakan pendapat dalam diskusi, mendengarkan pendapat orang lain, 
bekerja sama dengan anggota kelompok saat mengerjakan lembar kerja siswa, mempresentasikan hasil diskusi kelompok, mencatat materi pelajaran, belajar aktif merupakan langkah cepat, dan menyenangkan (Nasution, 2012:.28 - 29 ).

Pembelajaran tematik adalah pembelajaran terpadu yang menggunakan tema untuk mengaitkan beberapa mata pelajaran sehingga dapat memberikan pembelajaran bermakna bagi murid, tema adalah pokok pikiran atau gagasan pokok yang menjadi pokok pembicaraan.

Konsep pembelajaran tematik dalam historisnya merupakan hasil buah pemikiran dari dua orang tokoh pendidikan yakni jacob tahun 1989 dengan konsep pembelajaran interdisipliner dan fogarty pada tahun 1991 dengan konsep pembelajaran terpadu. Pembelajaran tematik merupakan suatu pendekatan dalam pembelajaran yang secara sengaja mengaitkan beberapa asfek baik dalam intramata pelajaran maupun antarmata pelajaran.dengan adanya pemandu itu peserta didik akan memperoleh pengetahuan dan keterampilan secara utuh sehingga pelajaran jadi bermakna bagi peserta didik (majid, 2014:85)

Beberapa pengertian pembelajaran tematik di atas menunjukkan bahwa pembelajaran tematik adalah pembelajaran yang menghubungkan siswa belajar secara kongkret tentang materi pelajaran yang ada di sekitarnya agar siswa bisa lebih memahami tentang konsep dan prinsip yang ingin di pelajari dan siswa harus terlibat aktif dalam proses pembelajaran mulai dari perencanaan, pelaksanaan hingga proses evaluasi. Pembelajaran tematik lebih berpusat pada siswa (student centered) dan lebih banyak menempatkan siswa sebagai subjek belajar sedangkan guru banyak berperan sebagai fasilitator.

Hasil pengamatan awal penulis di SDN 59/IX Penyengat Olak menemukan beberapa masalah pada proses pembelajaran tematik dan keaktifan belajar siswa belum optimal. Proses belajar di sekolah masih cenderung bersifat teoritis dan peran guru masih sangat dominan (teacher centered) dan gaya mengajar cenderung satu arah.

Metode pembelajaran yang sering digunakan oleh guru di dalam pembelajaran tematik adalah menggunakan metode ceramah dan siswa mendengarkan. Adapun metode lain yang jarang digunakan oleh guru adalah Make A Matc, mind map, dan demonstrasi. Hal ini telah membuat proses belajar mengajar menjadi monoton, kurang efektif, dan siswa sering berisik berbincang dengan temannya saat proses pembelajaran berlangsung, dan ketika ditanya ada yang tidak paham dengan pembelajaran siswa tidak merespon dengan baik dan ketika di beri latihan siswa sibuk bertanya kesana kemari.

Berangkat dari hasil observasi awal di SDN 59/IX Penyengat Olak, terlihat masih banyak siswa yang kurang aktif ketika guru selesai memberi penjelasan,serta masih banyak siswa yang tidak mengemukakan pendapatnya dalam diskusi ketika diberi pertanyaan siswa tersebut memilih diam dan tidak bisa menjawab apapun 
dan ketika ada kelompok lain yang mengemukakan pendapat, banyak kelompok yang tidak menanggapi atau mendengarkan dan malah berbicara dengan teman sebangku.dari skor hasil rata-rata observasi hanya mendapatkan skor 2 dengan jumlah skor 5, artinya dari 20 siswa hanya sekitar 8 siswa yang memenuhi standar ketuntasan minimal, dan berdasarkan kriteria dikatakan kurang aktif.

Asumsi awal penulis untuk dapat mengaktifkan para peserta didik dengan menggunakan metode team games tournament (TGT ). Teams Games Tournament (TGT) merupakan salah satu strategi pembelajaran kooperatif yang dikembangkan oleh De Vries dan Slavin (1995) untuk membantu siswa mereviuw dan menguasai materi pembelajaran. Slavin menemukan bahwa TGT berhasil meningkatkan SkilSkil dasar, pencapaian, interaksi positif antar siswa, harga diri dan sikap penerimaan pada siswa-siswa lain yang berbeda.

Dalam metode teams game tournament melibatkan aktivitas seluruh siswa tanpa harus ada perbedaan status, melibatkan peran siswa sebagai tutor sebaya dan mengandung unsur permainan dan penguatan. Dalam TGT, siswa mempelajari materi di ruang kelas, setiap siswa ditempatkan dalam satu kelompok yang terdiri dari 3 orang berkemampuan rendah, sedang dan tinggi. Komposisi ini di catat dalam tabel khusus (tabel tournament), yang setiap minggunya harus di ubah. Dalam TGT setiap anggota di tugaskan untuk mempelajari materi terlebih dahulu bersama anggota-anggotanya, barulah mereka diuji secara individual melalui game akademik. Nilai yang mereka peroleh dari game akan menentukan skor kelompok masing-masing. (Huda,2011: 197).

\section{METODE}

Penelitian ini menggunakan jenis penelitian tindakan kelas (PTK) yang memfokuskan pada situasi kelas atau di kenal sebagai classroom action research.(samsu sumandoy, 2013: 19) penelitian tindakan menekankan pada kegiatan (tindakan) dengan menguji cobakan suatu ide ke dalam praktek atau situasi nyata dalam skala micro dengan harapan tindakan tersebut mampu memperbaiki dan meningkatkan kualitas pada situasi nyata tersebut.

\section{Perencanaan (planing)}

Dalam penelitian ini dilakukan II siklus, langkah-langkah dalam tindakan selalu mengalami perbaikan peneliti mengidentifikasi terlebih dahulu masalah apa saja yang terjadi dalam proses pembelajaran, dengan cara observasi awal ke sekolah dan melihat bagaimana kegiatan pembelajaran, dan selanjutnya peneliti mewawancarai beberapa siswa yang terlibat dalam proses pembelajaran dan melakukan tanya jawab seputar pembelajaran tematik serta penggunaan model pembelajaran apa yang di pakai sehari hari.

Pada Tahap ini dilakukan rencana tindakan pada siklus meliputi kegiatan yang tersdiri dari:

Penggunaan Metode Team Games Tournament pada Pembelajaran... | Shalahudin 
1) Mempersiapkan silabus pembelajaran tematik.

2) Menyusun rencana pelaksanaan pembelajaran (RPP)

3) Menetapkan jadwal penelitian pada siklus I

4) Menetapkan materi bahan ajar siklus I

5) Menyusun skenario pembelajaran dengan menggunakan metode TGT

\section{Pelaksanaan}

Pelaksanaan dalam penelitian ini adalah langkah-langkah dari kegiatan perencanaan untuk memperbaiki masalah yang terjadi dalam pembelajaran tematik dengan menggunakan metode teams games tournament.

\section{Observasi (observing)}

Observasi adalah melihat serta mendokumtasi sejauh mana proses pembelajaran di kelas IV berlangsung. Dan mengamati aktivitas guru menerapkan metode teams game tournament.

\section{Refleksi (reflecting)}

Refleksi dilakukan setiap akhir siklus melihat kelemahan -kelemahan dari metode teams games tournament yang sedang berlangsung. Serta melihat hambatan apa yang dialami guru dalam menerapkan metode tersebut. Hasil dari refleksi siklus pertama menjadi bahan untuk melakukan suklus ke dua.

Jenis Instrumen yang digunakan adalah wawancara, observasi, dan dokumentasi. Teknik analisis data yang digunakan dalam penelitian ini adalah: mengumpulkan semua data dari hasil pengamatan siklus 1 Penelitian PTK., menganalisis data dengan membuat tabulasi presentase yang disajikan dalam bentuk tabel dan grafik, dan menguji keberhasilan penelitian dengan cara membandingkan hasil pengolahan data dengan indikator keberhasilan antara tes siklus I dan siklus II (Aunurrahman, dkk, 2009).

Peneliti juga menggunakan teknik triangulasi sebagai teknik untuk mengecek keabsahan data, dimana dalam pengertianya triangulasi adalah teknik pemeriksaan keabsahan data yang memanfaatkan sesuatu yang lain dalam membandingkan hasil wawancara terhadap objek penelitian (Moloeng, 2004:330), triangulasi dapat dilakukan dengan menggunakan teknik yang berbeda (Nasution, 2012:115) yaitu wawancara, observasi dan dokumen. Triangulasi ini selain digunakan untuk mengecek kebenaran data juga dilakukan untuk memperkaya data.

\section{HASIL}

Kondisi awal keaktifan belajar siswa kelas IV A di SDN 59/IX Penyengat Olak masih rendah. Kondisi tersebut dapat dinilai melalui proses pengamatan dan penilaian. Kondisi awal keaktifan belajar siswa kelas IV A di SDN 59/IX Penyengat dapat dilihat pada tabel berikut. 
Table 1

Persentase Kondisi Awal keaktifan Siswa

\begin{tabular}{|c|c|c|c|c|c|c|c|}
\hline \multirow{2}{*}{ No. } & \multirow{2}{*}{ Responden } & \multicolumn{5}{|c|}{ Indikator } & \multirow{2}{*}{ Skor } \\
\hline & & I & II & III & IV & V & \\
\hline 1 & $\mathrm{AA}$ & 1 & 1 & 2 & 2 & 2 & 8 \\
\hline 2 & $\mathrm{AM}$ & 1 & 2 & 1 & 2 & 2 & 8 \\
\hline 3 & $\mathrm{AR}$ & 1 & 1 & 2 & 2 & 2 & 8 \\
\hline 4 & CA & 2 & 2 & 1 & 2 & 2 & 9 \\
\hline 5 & DAS & 1 & 1 & 1 & 2 & 2 & 7 \\
\hline 6 & $\mathrm{ME}$ & 1 & 1 & 2 & 2 & 2 & 8 \\
\hline 7 & MKA & 1 & 1 & 1 & 2 & 2 & 7 \\
\hline 8 & $\mathrm{MM}$ & 2 & 2 & 1 & 2 & 2 & 9 \\
\hline 9 & MFAR & 1 & 2 & 2 & 2 & 2 & 9 \\
\hline 10 & MUP & 2 & 1 & 1 & 2 & 2 & 8 \\
\hline 11 & $\mathrm{MF}$ & 1 & 2 & 1 & 2 & 2 & 8 \\
\hline 12 & MFA & 1 & 1 & 2 & 2 & 2 & 8 \\
\hline 13 & NN & 2 & 1 & 1 & 2 & 2 & 8 \\
\hline 14 & NSA & 2 & 2 & 1 & 2 & 2 & 9 \\
\hline 15 & $\mathrm{NJ}$ & 1 & 1 & 2 & 2 & 2 & 8 \\
\hline 16 & PA & 1 & 1 & 2 & 2 & 2 & 8 \\
\hline 17 & $\mathrm{RS}$ & 2 & 1 & 2 & 2 & 2 & 9 \\
\hline 18 & RA & 1 & 2 & 1 & 2 & 2 & 8 \\
\hline 19 & RA & 2 & 1 & 2 & 2 & 2 & 9 \\
\hline 20 & $\mathrm{RP}$ & 1 & 1 & 1 & 2 & 2 & 7 \\
\hline \multicolumn{2}{|c|}{ Jumlah } & 28 & 26 & 29 & 40 & 40 & 163 \\
\hline \multicolumn{2}{|c|}{ Jumlah Ideal } & 100 & 100 & 100 & 100 & 100 & 500 \\
\hline \multicolumn{2}{|c|}{ Presentase } & $28 \%$ & $26 \%$ & $29 \%$ & $40 \%$ & $40 \%$ & $32.6 \%$ \\
\hline
\end{tabular}

Keterangan :

$\mathrm{Mx} \quad=$ Mean yang dicari (skor rata-rata)

$\Sigma \mathrm{x} \quad=$ Jumlah dari skor-skor (nilai-nilai) yang ada 
$\mathrm{N}=$ Jumlah Ideal (banyaknya skor-skor itu sendiri)

Dengan penilaian:

$0-19=$ Tidak aktif

$20-59=$ Kurang aktif

$60-69=$ Cukup aktif

$70-79=$ Aktif

$80-100=$ Aktif sekali

Data table di atas menunjukan bahwa kondisi awal keaktifan belajar siswa siswa sekolah dasar negeri 59 /IX penyengat olak masih sangat rendah, rata-rata siswa dikatakan masih kurang aktif, dari sinilah peneliti mulai melakukan penelitian tindakan kelas guna untuk memperbaiki pembelajaran dan meningkatkan keaktifan siswa pada pembelajaran tematik dengan menggunakan metode TGT teams games tournament.

Secara keseluruhan dapat disimpulkan bahwa keaktifan siswa kelas IV SDN 59/IX Penyengat Olak termasuk ke dalam kategori "Kurang Aktif" hasil tersebut di sebabkan karena saat proses pembelajaran tematik guru masih menggunakan metode pembelajaran yang berpusat pada guru, dimana lebih banyak menggunakan metode ceramah saat proses pembelajaran.

\section{SIKLUS I}

Pelaksanaan tindakan siklus I ini terbagi beberapa tahapan, yakni perencanaan tindakan, pelaksanaan tindakan, observasi, evaluasi dan refleksi.

1) Perencanaan

Pada tahap perencanaan peneliti dan guru berkolaborasi menyusun rencana pelaksanaan pembelajaran (RPP) tematik yang akan di pelajari dengan model Teams Games tournament, pada Siklus I materi yang akan diajarkan kepada peserta didik pada tema 7 sub tema 1 keragaman suku bangsa dan agama dinegeriku, pembelajaran I. bahan ajar yang digunakan yaitu, kertas karton yang di temple di papan tulis sebagai daftar rangking siswa, dan kartu-kartu yang berupa daftar pertanyaan dan jawaban, mempersiapkan lembar observasi keaktifan belajar siswa dan lembar observasi mengajar guru. Menyiapkan alat dokumentasi sebagai penunjang proses pembelajaran.

2) Pelaksanaan

Pada tahap ini peneliti dan guru berkolaborasi menyusun rancangan yang akan dilaksanakan, yaitu menyusun Rencana Pelaksanaan Pembelajaran (RPP) tahap pelaksanaan siklus I. Pelaksanaan tindakan penelitian dilakukan dua kali pertemuan pemberian tindakan, dan satu kali pertemuan pemberian angket akhir siklus I untuk mengukur hasil keaktifan siswa selama proses 
pembelajaran yang dilakukan selama 2 X 35 menit atau dua jam pelajaran dengan materi, keragaman suku bangsa di indonesia dan gaya.

3) Hasil observasi, yaitu dilakukan dengan mengamati aktivitas peserta didik dan aktivitas guru.

4) Refleksi, yaitu dilakukan setelah melewati tahap pelaksanaan tindakan dan tahap observasi. Kegiatan refleksi dimaksudkan untuk mengetahui apakah tindakan yang dilakukan pada siklus I sudah mengalami peningkatan.

\section{Siklus II}

1) Perencanaan

Pembelajaran siklus II masih sama dengan siklus sebelumnya hanya saja guru lebih dimaksimalkan dalammembimbing siswa dalam memotivasi meningkatkan keaktifan belajar. Pada siklus II materi yang akan diajarkan adalah keragaman suku bangsa dan agama di Indonesia.

2) Pelaksanaan.

Pada tahap ini peneliti dan guru berkolaborasi menyusun rancangan yang akan dilaksanakan penelitian dilakukan dalam dua kali pertemuan pemberian tindakan, dan dalam sati kali pertemuan tes angket akhir siklus II untuk mengukur hasil keaktifan siswa selama proses pembelajaran yang dilakukan selama 2X35 menit atau 2 jam pelajaran dengan materi "suku bangsa di Indonesia dan gaya".

3) Hasil Observasi, yaitu dilakukan dengan mengamati aktivitas peserta didik dan aktivitas guru.

4) Refleksi, yaitu dilakukan setelah melewati tahap pelaksanaan tindakan dan tahap observasi. diketahui hasil keaktifan siswa pada siklus II dalam kategori sangat aktif, yaitu presentasi skornya mencapai 88\%.

Berdasarkan hasil refleksi tersebut penelitian pada siklus II dikatakan sudah berhasil karena sudah memenuhi indikator keberhasilan tindakan yang telah di tetapkan, yaitu adanya peningkatan aktivitas belajar sisw adanya peningkatan keaktifan siswa kedalam kategori mendekati sangat aktif .maka pemberian tindakan pada penelitian diakhiri pada siklus II.

\section{Analisis Data}

Tahap analisis data dilakukan setelah semua data terkumpul, data tersebut berupa hasil observasi aktivitas belajar siswa, hasil observasi aktivitas mengajar guru, dan observasi keaktifan siswa. Hasil data yang diperoleh dari pengumpulan data dengan teknik observasi adalah sebagai berikut:

1) Hasil observasi aktivitas belajar siswa pada siklus I diperoleh rata-rata persentase sebesar 74\%, sedangkan pada siklus II diperoleh rata-rata persentase sebesar $88 \%$. Hal ini menunjukan adanya peningkatan aktivitas 
belajar siswa dalam proses pembelajaran Tematik dengan menggunakan Metode Teams Games Tournament.

2) Hasil observasi aktivitas mengajar guru pada siklus I diperoleh rata-rata persentase sebesar89\%, sedangkan pada siklus II diperoleh rata-rata persentase sebesar 92\%. Hal ini pun menunjukan adanya peningkatan kemampuan guru dalam mengelola kelas sehingga mampu meningkatkan keaktifan belajar siswa.

3) Hasil observasi keaktifan belajar siswa pada siklus I diperoleh rata-rata persentase sebesar 63\%, sedangkan pada siklus II diperoleh rata-rata persentase sebesar 88\% dengan kategori sangat aktif. Hal ini menunjukan adanya peningkatan keaktifan siswa pada pembelajaran Tematik dengan menggunakan Metode Teams Games Tournament.

\section{PEMBAHASAN}

Kegiatan pembelajaran dengan menerapkan metode teams games tournament telah memperoleh hasil yang cukup efektif dalam pelaksanaan proses pembelajaran Tematik di SDN 59/IX Penyengat Olak. Hal ini dapat terlihat dari adanya peningkatan aktivitas belajar siswa dan guru dengan menggunakan metode Teams Games Tournament.

Hal ini sesuai dengan penjelasan Sani, Ridwan dan Abdullah (2013) yang menjelaskan bahwa metode teams games tournament dapat mendorong dan mengkoordinasi berkembangnya sikap dan keterampilan sosial siswa, meningkatkan hasil belajar serta aktivitas siswa, meningkatkan penguasaan siswa terhadap materi pembelajaran, membuat proses belajar mengajar lebih berorientasi pada siswa, dan mendidik siswa untuk bersosialisasi dengan orang lain.

Selain itu, hasil observasi di kelas IV menemukan bahwa keaktifan siswa sebelum dan sesudah diterapkannya metode Teams Games Tournament ini telah mengalami perubahan dari pra siklus ke siklus I dan dari siklus I ke siklus II. Peningkatan aktivitas belajar siswa juga diamati sejalan dengan peningkatan keaktifan belajar siswa. Persentase skor rata-rata keaktifan siswa pada siklus satu adalah sebesar 61\% dengan kategori "cukup aktif" dan persentase skor rata-rata keaktifan siswa pada siklus dua meningkat menjadi 93\% dengan kategori "sangat aktif".

\section{SIMPULAN}

Hasil penelitian ini telah menunjukkan bahwa penggunaan metode teams games tournament di dalam proses pembelajaran tematik telah dapat meningkatkan keaktifan belajar siswa. Hal ini ditunjukkan oleh peningkatan nilai aktivitas belajar siswa dari pra siklus (32,6\%), ke siklus I (61\%) dan siklus II (93\%). Selain itu, hasil 
penelitian ini juga menunjukkan pentingnya keterlibatan siswa di dalam proses pembelajaran. Oleh karena itu, guru sekolah dasar disarankan untuk menggunakan metode teams games tournament dan metode pembelajaran aktif lainnya untuk meningkatkan keterlibatan siswa di dalam proses pembelajaran.

\section{DAFTAR PUSTAKA}

Ahmadi, Rulam. (2017). Pengantar Pendidikan Asas dan Filsafat Pendidikan. Yogakarta: Ar Ruzz Media.

Asih, B. (2018). Penerapan Model Pembelajaran Kooperatif Tipe TGT Melalui Teknik Bermain Guna Meningkatkan Minat dan Hasil Belajar Fisik Peserta Didik Kelas X SMA N 1 Pundong. SKRIPSI, Jurusan Pendidikan Fisika, Fakultas Matematika Dan Ilmu Pengetahuan ALam, UNiversitas Negeri Yogyakarta. SKRIPSI, Jurusan Pendidikan Fisika, Fakultas Matematika Dan Ilmu Pengetahuan ALam, UNiversitas Negeri Yogyakarta.

Batubara, H. H. (2020). Media Pembelajaran Efektif. Semarang: Fatawa Publishing.

Dewi Nuryani, T., Rosadi, K. I., \& Azim, P. (2019). Penerapan Pembelajaran Tematik Memggunakan Model Pembelajaran Kooperatif Tipe TGT (Teams Games Tournaments) Untuk Meningkatkan Keaktifan Belajar Siswa Kelas IV Di Madrasah Ibtidaiyah Negeri 4 Muaro Jambi (Doctoral dissertation, UIN Sulthan Thaha Saifuddin Jambi).

Huda, Miftahul, (2013). Model-Model Pengajaran dan Pembelajaran, Yogyakarta: Pustaka Pelajar.

Majid, Abdul. (2014 ), PembelajaranTematikTerpadu. Bandung: PT Rosdakarya

Nasution, A. M. (2012). Upaya Meningkatkan Keaktifan Belajar Siswa melalui Model Pembelajaran Kooperatif Tipe Team-Game-Tournament (TGT) dengan Media Teka-teki Silang (TTS) pada Mata Pelajaran Ilmu Pengetahuan Alam (IPA) di Kelas IV A MI Sultan Agung Yogyakarta. Laporan penelitian tidak diterbitkan. Yogyakarta: Lembaga Penelitian dan Pengabdian kepada Masyarakat Universitas Negeri Yogyakarta.

Nurhayati, E. (2020). Meningkatkan keaktifan siswa dalam pembelajaran daring melalui media game edukasi quiziz pada masa pencegahan penyebaran covid19. Jurnal Paedagogy, 7(3), 145-150.

Prasetyo, A. D., \& Abduh, M. (2021). Peningkatan Keaktifan Belajar Siswa Melalui Model Discovery Learning Di Sekolah Dasar. Jurnal Basicedu, 5(4), 1717-1724.

Sani,Ridwan, Abdullah. (2013). Inovasi Pembelajaran. Jakarta: Bumi Aksara

Sareong, I. P., \& Supartini, T. (2020). Hubungan Komunikasi Interpersonal Guru dan Siswa Terhadap Keaktifan Belajar Siswa di SMA Kristen Pelita Kasih Makassar. Jurnal Ilmu Teologi dan Pendidikan Agama Kristen, 1(1), 29-42. 
Setiawan, M. A., \& Yuswono, L. C. (2017). Penerapan metode pembelajaran Team Game Tournament (TGT) untuk meningkatkan keaktifan dan hasil belajar. EJurnal Pendidikan Teknik Otomotif-S1,20(1).

Siregar dan Nara, (2010 ). Teori Belajar Dan Pembelajaran. Bogor: Ghalia

Susanto, Ahmad (2016 ). Teori Belajar dan Pembelajaran di Sekolah Dasar. Jakarta: Prenada Media Group.

Thalita, A. R., Fitriyani, A. D., \& Nuryani, P. (2019). Penerapan Model Pembelajaran Tgt Untuk Meningkatkan Keaktifan Belajar Siswa Kelas Iv. Jurnal Pendidikan Guru Sekolah Dasar, 4(2). 